\title{
顎関節脱自整復術の工夫
}

\author{
佐 藤 公 則112)

\section{Reduction Procedure for Dislocated Temporo-Mandibular Joint}

\author{
Kiminori Sato \\ (Sato Clinic \& Hospital, Kurume University School of Medicine)
}

\begin{abstract}
Since before Christ, Hippocrates' procedure was well known as a manual reduction procedure for acute temporomandibular joint (TMJ) dislocation. In this paper, the modified manual reduction procedure for acute TMJ dislocation is introduced.

First of all, the operator asks the patient to sit on the floor against the wall with his or her legs out straight. Then the operator stands facing the patient with his feet on either side of the patient's legs. The operator holds the patient's mandible with his thumbs on the bilateral occlusal surface of molar. Bilateral thumb pressure is exerted inferiorly and posteriorly. The operator leans his bodyweight forwards with straight arms when it is hard to replace the head of the mandible. After reduction of the mandible, it is common for the patient to bite the operator's thumbs. So the operator should move his thumbs outside of the teeth (to the oral vestibule). Restriction of mandibular motion for a few days is advisable.

Thirteen patients with acute TMJ dislocation underwent this manual reduction procedure. In all cases, the condylar head of the mandible was dislocated anteriorly.

The advantage of this manual reduction procedure is that even when the patient's muscle tension is strong and operator's physical strength is weak, it is not very hard to perform manual reduction of acute TMJ dislocation.
\end{abstract}

Key words : reduction procedure, temporomandibular joint dislocation, temporomandibular joint

\section{はじめに}

顎関節が生理的関節可動域を超える運動を強制され， 下顎頭が転位した場合を顎関節脱曰という.プライマリ・ ケアの現場で遭遇する可能性が高いのは顎関節前方脱臼 (下顎頭が関節結節の頂点より前方に移動し,関節窩に戻 ることが妨げられている) の新鮮例である.

顎関節脱臼の徒手整復法は, 紀元前からヒポクラテス 法 (Hippocrates' method：図 1) が用いられている1).こ の方法は患者を椅子に腰掛けさせて助手が患者の頭を固 定し，術者が患者の前に立つ体位で顎関節脱臼の徒手整 復を行う。本論文では著者が現在行っている顎関節脱臼
の徒手整復法2) の有用性を報告する.

\section{対象}

対象は 1994 年 1 月から 2005 年 8 月の間に佐藤クリニッ ク（大分市）で本法を用いて顎関節脱目整復術を行った 13 例である. 年齢は $19 \sim 74$ 歳 $(41 \pm 21$ 歳), 男性が 7 例, 女性が 6 例である. 脱臼の種類はすべて完全前方脱 曰（図 $2 \mathrm{~A}, \mathrm{~B}$ ) であり, 両側脱臼が 9 例, 右側脱臼が 3 例, 左側脱臼が 1 例であった. 初回脱臼例が 3 例, 反復 脱臼例が 10 例であった. 顎関節脱臼の原因は大きな欠伸 が 7 例, 食事中の過度の顎運動が 3 例, 会話中の過度の

1）佐藤クリニック耳鼻咽喉科（大分市）

2) 久留米大学耳鼻咽喉科・頭頸部外科学講座 


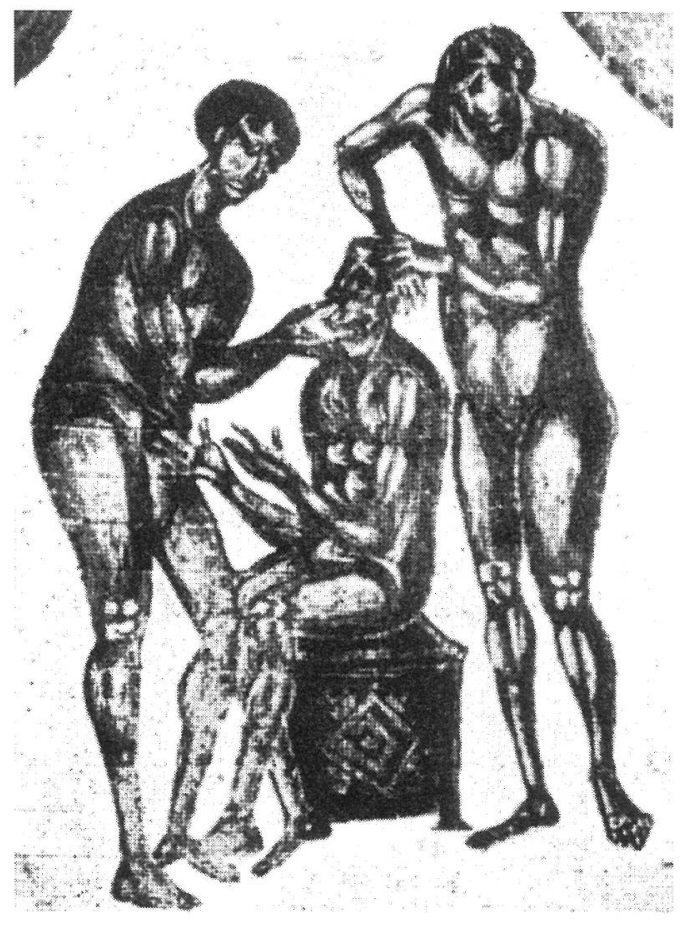

図 1 頼関節脱臼整復術（Hippocrates' method）（文献 1 より）
顎運動が 1 例, 歯科治療中の過度の顎運動が 1 例, 咽頭 手術中の過度の顎運動が 1 例であった。

\section{顎関節脱臼徒手整復術}

1. 患者を床に座らせ，壁に背をもたれかからせ，術者 が患者の両足をまたいで患者の前に立つ体位で徒手整復 術を行ら（図 3)。

2. 術者は自分の両側拇指を患者の両側下顎臼歯咬合 面にあて,他の4指で口腔外から下顎体を把持する (図4)。

3. 術者は自分の腕を伸展させ, 拇指で両側下顎曰歯咬 合面を下方へ押し下げる（図 4 の矢印 1)。この際に他の 4 指で頡部を固定しテコの原理で拇指を下方に押し下げ るとよい。患者の筋緊張が強く, 術者の力が弱い場合は, 術者は自分の体重をかけてこの操作を行う。

4. 次に下方へ押し下げた下顎を後方へしゃくり上げ るように操作し（図 4 の矢印 2）脱臼した顎関節を整復 する。患者に指をかまれないように整復時は拇指にガー ゼを巻いてもよいが，顎関節が整復される瞬間に目歯咬 合面から口腔前庭部へ拇指を移動させると患者に指をか まれない。

5. 徒手整復後の固定は重要である. 過度の開口を禁止

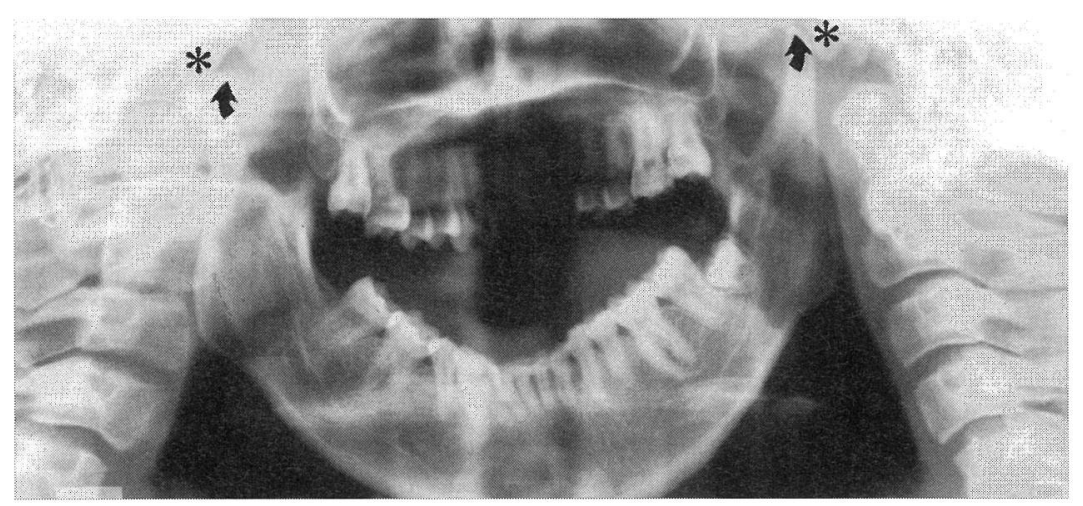

A

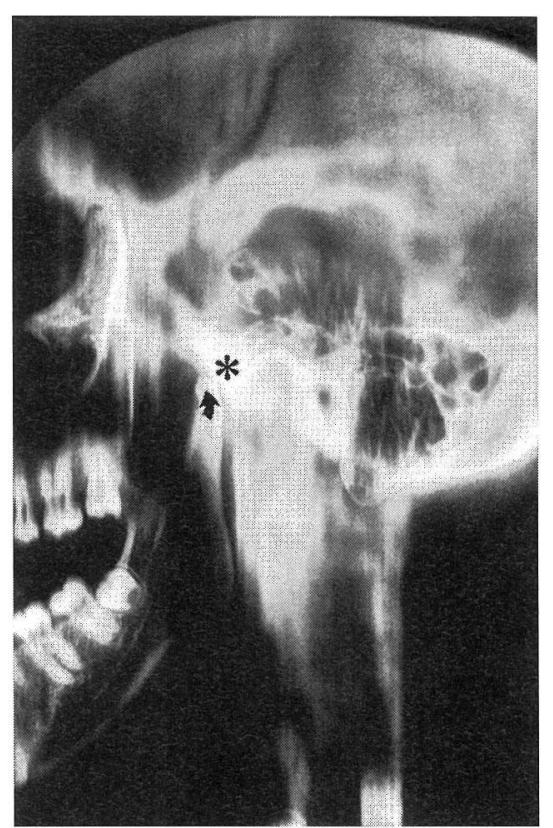

$\mathrm{B}$

図 2 両側頡関節前方脱臼（A：パノラマX 線撮影法，B：断層撮影法） 下顎頭 (矢印) が関節結節の頂点（*）より前方に移動している. 


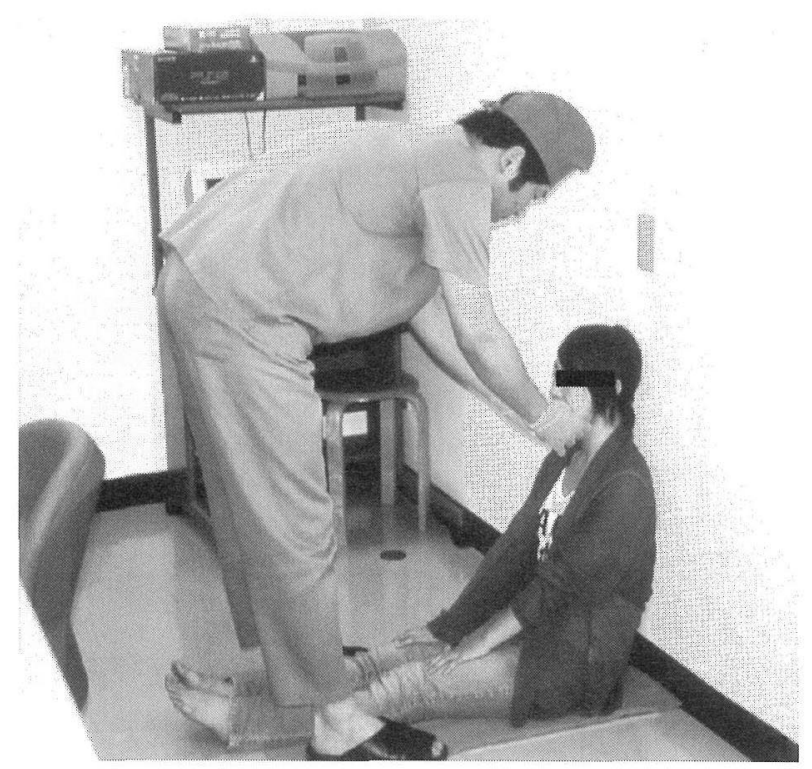

図 3 顎関節脱臼徒手整復術の体位

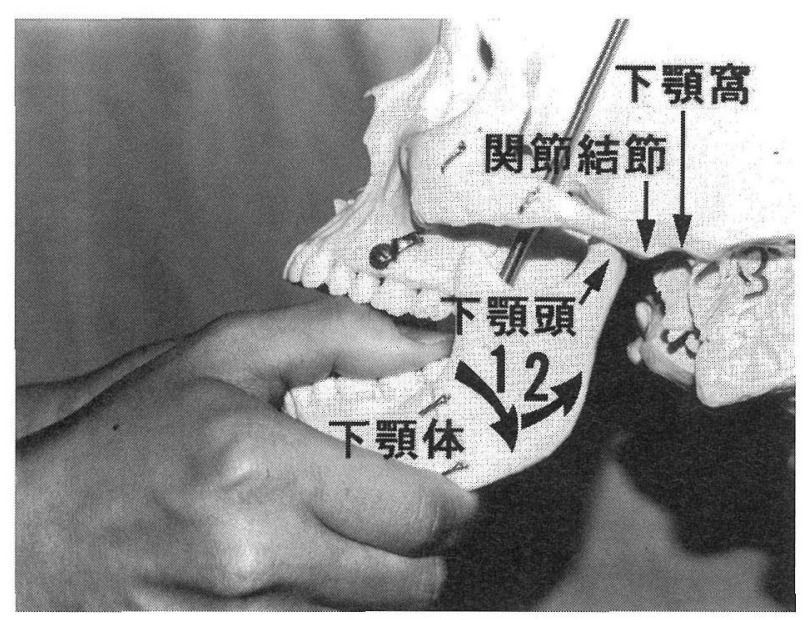

図 4 下顎の把持法と徒手整復術

下方へ押し下げた下䪽体（矢印 1）を後方へしゃくり上げ る（矢印 2) ように整復する.

し，数日間弾力包帯などで固定を行う（図 5).

\section{結果}

筋緊張が強い患者でも前投薬を行わずに全例で顎関節 脱臼の徒手整復が行え, 整復術が困難であった例はな かった。本法では患者の頭部は壁で固定され，助手の必 要がなく, 1 人の術者で顎関節脱臼の整復術が行えた. 術 者は自分の体重をかけて徒手整復術が行える利点があ

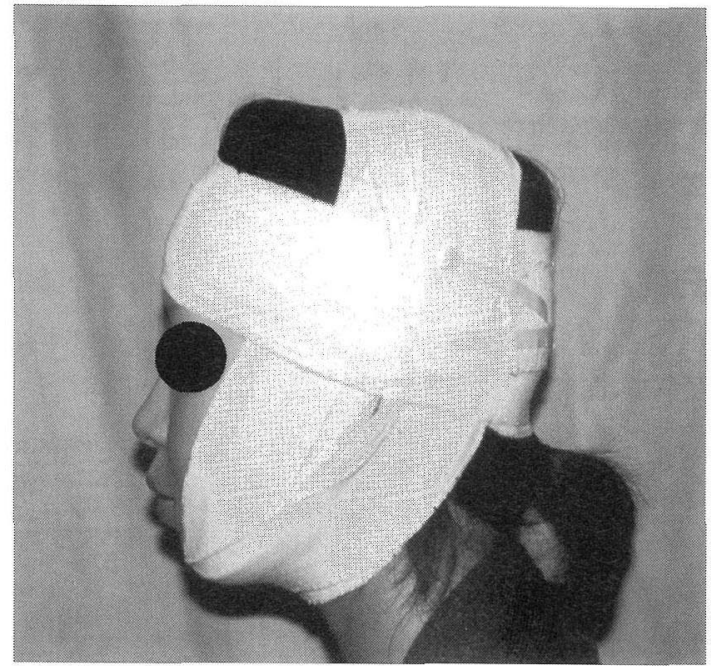

図 5 弾力包帯による顎関節脱曰整復術後の固定

り，患者の筋緊張が強く，術者の力が弱い場合でも顎関 節脱臼の徒手整復法が困難なく行えた。

\section{考察}

顎関節脱臼には新鮮例と陳旧例，また反復して脱臼す る習慣性脱臼がある。顎関節脱臼は脱臼の方向から前方, 側方，後方の各脱臼に分類されるが，プライマリ・ケア の現場で遭遇する顎関節脱臼の大部分は前方脱臼であ る.

顎関節脱臼の徒手整復法は, 紀元前からヒポクラテス 法 (Hippocrates' method）が用いられており1)，急性脱田 の処置方法は昔からあまり変化せずに伝えられてきてい る3).ヒポクラテスによって記述された整復法は以下の ごとくである3 .1 人が患者の頭をしっかりと固定しなけ ればならない。いま 1 人の人が頣部を指ではさむように して下顎を把持する．患者にできるがぎり口大きく開 けさせる。まず，しばらくの間下顎を動かし，手をそえ て顎を脱臼側へ押しやる。患者に顎をゆるめて, 顎を動 かすように指示し，それをできるかざりやらせる。それ から次の 3 つの点に同時に注意をしながら，術者は患者 の口を突然に開けなければならない。下顎が転位した位 置から自然の位置に動かされるといらこと，後方に押し やられること，および上下顎がこの線に沿ってともに動 かされ，そして閉じたままになること ${ }^{3)}$ 。この整復法で は患者の筋緊張が強く, 術者の力が弱い場合に顎関節脱 臼の整復が難しいことがある. 
その他患者を椅子に腰掛けさせて術者が患者の後ろに 立つ体位で, 患者の頭部を術者の腹部で保持して顎関節 脱臼の徒手整復を行ら方法もある ${ }^{3}$. 下顎の把持の方法 も両方の歯間に木片をおく方法 ${ }^{3)}$ ，拇指を臨部にあてる 方法4) などがある.

今回検討した顎関節脱臼の整復方法の利点は, (1)筋緊 張が強い患者でも全例で前投薬を行わずに靧関節脱臼の 徒手整復が行え, 整復術が困難であった例はなかった。 (2)本法では患者の頭部は壁で固定され, 助手の必要がな く, 1 人の術者で顎関節脱臼の整復術が行えた. (3)術者 は自分の体重をかけて徒手整復術が行える利点があり, 患者の筋緊張が強く, 術者の力が弱い場合でも顎関節脱 臼の徒手整復法が困難なく行えたことであった。

本論文の要旨は, 第 109 回日耳鼻大分県学術講演会 $(2006$ 年 1月 21 日, 大分) で口演した.

\section{参考文献}

1）Laszlo Schwartz : 顎関節についての考え方と治療法の進歩. 䪽関節異常 顎関節疾患の診断，取扱い，咬合との関係 (Laszlo Schwartz 編, 河村洋二郎訳), $3 \sim 4$ 頁, 医歯薬出 版, 東京, 1962.

2) 佐藤公則：䫟関節脱臼. JIM $15: 468 \sim 469,2005$.

3) Laszlo Schwartz : 脱臼と亜脱臼. 顎関節異常 顎関節疾患 の診断，取扱い，咬合との関係（Laszlo Schwartz 編，河村 洋二郎訳), $323 \sim 338$ 頁, 医歯薬出版, 東京, 1962 .

4) Nicholas Georgiade : Disturbances of the temporomandibular joint. Reconstructive Plastic Surgery. Volume Three (ed by Converse JM), pp $1526 \sim 1527$, W. B. Saunders Co., Philadelphia, 1977.
原稿受付 : 平成17年10月11日

原稿採択：平成17年11月30日

別刷請求先：佐藤公則

于870-0026 大分市金池町2-8-18

佐藤クリニック耳鼻咽喉科 